\title{
Semiotic autoregulation: Dynamic sign hierarchies constraining the stream of consciousness
}

\author{
Jaan Valsiner \\ Department of Psychology, Clark University \\ 950 Main Street, Worcester, Ma. 01610, USA \\ e-mail: jvalsiner@clarku.edu
}

\begin{abstract}
For all human sciences, understanding of how the mind works requires a new theory that starts from the assumption of potential infinite variability of human symbolic forms. These forms are socially constructed by the person who moves through an endless variety of unique encounters with the world. A theory of symbolic forms needs to capture the essence of hyperdynamic, irreversible nature of the stream of consciousness and activity. The human mind is regulated through a dynamic hierarchy of semiotic mechanisms of increasingly generalized kind, which involves mutual constraining between levels of the hierarchy. It is demonstrated that semiotic mediation leads to a triplet of personal-cultural constructions - a new symbolic form, a metasymbolic form, and a regulatory signal to stop or enable the construction of further semiotic hierarchy. In everyday terms - human beings produce new problems, together with new efforts at solving them, and make decisions when to stop producing the former two. Hence, semiotic mediation guarantees both flexibility and inflexibility of the human psychological system, through the processes of abstracting generalization and contextualizing specification. Context specificity of psychological phenomena is an indication of general mechanisms that generate variability. Scientific investigation of human psychological complexity is necessarily oriented to the study of variability within the individual person's psychological time-space.
\end{abstract}


I have created the world in thought

Hence I am greater than thought

But I worship thought

Is this not surprising?

Ramamirtham (1986)

Human beings are amazing - they create subjective worlds of high complexity - and take it to be objective reality. They organize their mental realms through continuously creating hierarchies of semiotic mediating devices. These devices regulate their relations with their immediate environments by giving meaning to their extra-actions that change the environments, and intra-actions that change their own subjective worlds. Persons create deeply subjective and abstracted from the immediate life meanings - which are at times personified in terms of deities - various "personal gods" for whom shrines can be constructed (Oliveira, Valsiner 1997; Valsiner 1999). Other persons a Juliet for a Romeo, or film star for an adolescent - may become vehicles for such construction of hyper-generalized personal sense systems that operate with holistic field-like signs (Valsiner 2005, 2006). Pictorial images of idealized "social others" — Baoule "wooden spouses" (Ravenhill 1996; Vogel 1997) or images of the madonna in Catholic homes - are iconic signs for regulating one's own self. All of these cultural forms are symbolic resources (Zittoun 2006, 2007; Zittoun et al. 2004) that function as external regulators of the intra-psychological cultural domains. The acts of Psyche operate through a multi-faceted process of semiosis in which persons set their goals, and act in ways that give meaningfulness for their movement towards these goals (Rosa 2007; Salgado, Gonçalves 2007).

At the same time, the realities of the social world guide the persons towards some - rather than other - objectives (Valsiner 2007). The ancestors are to be honored, political leaders are to be followed, despised, deposed, or elected, wars are to be fought as activities of "patriotic duty", and children made for the sake of self-fulfillment, "reproductive success", or for replenishing the human resources of a given social order. In the theatre of human living, we are actors and

Quoted via Eichinger Ferro-Luzzi 2002: 128. 
spectators at the same time. We - as unique individuals with hard to penetrate layers of defense of our privacies - are at the same time completely dependent upon the resources of the semiosphere that we live with. Our personal uniqueness is the result of our social belonging. At that boundary of persons' relations with the signs-infested environments, persons create ever new signs and use these for creating further personal uniqueness. How does that happen?

\section{The generic personal act of semiosis}

In the generalized form, such acts of personal-cultural creation can be summarized by the following:

the person constructs meaning complex $x \ldots$

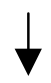

...objectifies it by fixing its form...,

(e.g. internal - internalized social norm, or external - monument, picture of deity, figurine)

...and starts to act as if the objectified meaning complex $x$

is an external agent that controls the person

It is here where culture enters into the human psyche - and infinitely complicates the construction of the sciences of the human mind. All scientific terminology - similarly to its everyday counterpart - is in fact a version of such regulating system. It is that part that is meant to objectively and abstractly explain the complexity of our psychological phenomena - a scientific theory is a kind of a mental cathedral that stands in the center of the booming and buzzing confusion we call living a life. 


\section{Homage to Henri Bergson: uniqueness of irreversibility}

The philosophy of Henri Bergson is perhaps too famous to be advanced further. This happens when a particular thinker becomes hailed as a guru figure by all too ardent followers - who fail to see that his (or her) ideas are only unfinished sketches of a bigger picture of understanding the complex nature of what is being studied.

When the educated public in Paris tried hard to get to Bergson's presentations in early 20th century - and gossiped about his mysticism of the élan vital - the major role he played in the advancement of the developmental science may have been overlooked. In his Creative Evolution (1945 [1907]), Bergson synthesized the basic knowledge about language, evolution, and development that came out of the 19th century thought, and created the basis for the 20th century developmental science. The key figures of that science - Jean Piaget and Lev Vygotskij (to mention just a few) picked up the ideas and put them to practice. Yet much of it has gone forgotten - and that forgetting has hindered the development of sciences over the past century.

\section{Adaptation is apprehensive}

A central concept important for a developmentally open cultural (as well as evolutionary) psychology was Bergson's notion of adaptation. That concept — popular as it was (and is), can carry different meanings. First, it has been seen as direct reaction to the conditions that are causing change - either "positive" (by way of giving rise to new variations) or "negative" (elimination of misfitting emerged variations). Bergson disagreed with both of these meanings - on the basis of the mechanistic nature (Bergson 1911a: 63). Instead, he focused on adaptation as the process of emergence of novel mechanisms in ways coordinated with context demands. Thus - adaptation does not mean that environment "molds" or "shapes" the organism. Instead, the environment triggers the emergence of new forms biological and symbolic alike. These forms go beyond the demands of the here-and-now environment, rather than "fit with" it.

Thus, human psychological development of the higher psychological functions leads to new organizational forms that make it 
possible for the human beings to encounter new possible conditions in the future. Of course the demands of the future cannot be pre-set in the present - even with full knowledge of the past. Hence the emergent new forms are crucial in bridging the past and the upcoming future (Bergson 1911 $\mathrm{a}^{2}$ ).

In sum - in the case of creative adaptation, the organizational forms that emerge in adaptation go beyond the "fit with" the present state of the survival conditions, and set the basis for facing the challenges of the possible future demands.

Bergson's notion of becoming was expressed on the material of human personality in his characteristic ways:

Our personality, which is being built up at each instant with its accumulated experience, changes without ceasing. By changing it prevents any state, although superficially identical with another, from forever repeating it in its very depth [En changeant, elle empêche un état, fût-il identique à lui-même en surface, de se répéter jamais en profondeur]. That is why our duration is irreversible. We could not live over again a single moment, for we should have to begin by effacing the memory of all [souvenir de tout] that had followed. (Bergson 1911a: 8; French versions inserted from Bergson 1945 [1907]: 23)

[...] to foresee consists of projecting into the future what has been perceived in the past, or of imagining for a later time a new grouping, in a new order, of elements already perceived. But that which has never been perceived, and which is at the same time simple, is necessarily unforeseeable. Now such is the case with each of our states, regarded as a moment in a history that is gradually unfolding [...]. It is an original moment of a no less original history. (Bergson 1911a: 9, emphasis added)

Bergson's emphasis on the role of acting upon one's environment as functional in development sets him up as a forerunner of our contemporary activity theories - starting with those of Pierre Janet (e.g., Bergson, 1911b: xix, 151, 229, etc.; for an analysis of Janet's activity theory see Valsiner, van der Veer 2000). The traditions of Bergson and Janet played a crucial role in the development of the Russian cultural-historical school of thought of Lev Vygotskij and Aleksander Luria (van der Veer, Valsiner 1991).

2 Discussion of canalizing involved in vision - Bergson 1911a: 105-108; and in the role of concepts in canalizing conscious processes - Bergson 1911a: 305308 . 


\section{Jaan Valsiner}

The issue at stake here is the constructive use of the history of scientific thought. The ideas of the past thinkers are not just "museum specimens", but examples of the construction of epistemic tools. Some of the "old" construction ideas surpass some of our contemporary ones - and vice versa. Bergson's ideas were well ahead of his time, as they attempted to capture a very crucial side of human mental dynamism.

\section{Maintained stability of the hyper-dynamic mind}

In the world of social sciences that tend to fight the perils of "Cartesian dualisms", it would probably sound old-fashioned to make the simple claim - the human experience is dual. Its duality is that of the unity of stability and dynamism. The human mind maintains itself as open-ended and dynamic - its socially organized forms (stability) operate in always unique contexts that are given by the irreversible nature of time (the dynamics of forms). Combining these two within one single theoretical framework would entail the creation of a substantive science of social being. This task is still ahead for our contemporary social sciences. The difficulties here are theoretical, rather than practical (or social).

Experience that proceeds within irreversible time, and is dependent upon constant interchange with the environment, entails indeterminacy that defies prediction and control of future outcomes. Instead, it is filled with constant emergence, proliferation, and extinction of 'intermediate gestalts' (in terms of the classical theory of microgenesis - Valsiner, van der Veer 2000: ch. 7). So, in other terms - most of the human meaning-making process is not directly reflected in the static (final) symbolic forms - but vanish without trace during the process of construction of such forms. The easy availability of outcomes of symbolic constriction hides the processes that produce these outcomes. This feature of our access limitations to relevant phenomena is most clearly visible in the case of rating scales and questionnaires (Valsiner, Diriwächter, Sauck 2005; Wagoner, Valsiner 2005).

This feature of the mismatch of the process and outcome within the human mind invalidates the hopes of pragmatist philosophy - which uses consequences — or 'final gestalts' — as the criterion of truth. 
For pragmatism, consequence (surviving experience) proves the righteousness of the survival process - yet from these consequences we cannot analyze the ways of producing them (Valsiner 2000). Pragmatism attempted to unite the focus on the dynamic processes of experiencing with static evaluation of these processes (through outcomes) - a conceptual task of utmost complexity. They failed - as they could not consider the relevant feature of signs - their capacity to create new signifying possibilities, or their ontopotentiality (Valsiner 2002). The power of signs has been conceptualized in theoretically productive ways by another thinker - who as often been considered to belong to the "pragmatist tradition"3 — Charles Sanders Peirce.

\section{From duality to triality: the functional infinity of semiosis}

Life experience - viewed within Bergsonian time - is infinite until the moment it ends. How can we look at the proceeding experience as the time never allows for repetition of it? There is a basic feature of all organic matter: it is being born from the past, and the opposite idea — the past emerging from the future — cannot take place. This recognition is also at the foundation of James Mark Baldwin's "genetic logic" (Baldwin 1906): development cannot be represented by convertible propositions $(\mathrm{A} \rightarrow \mathrm{B}$ is not $\mathrm{B} \rightarrow \mathrm{A})$. The irreversibility of time breaks the symmetry (Prigogine 1973). Furthermore duality of an opposition is not sufficient for explaining the emergence of novelty - a third component needs to be added to an oppositional duality to make it transform into a new form (Nöth 1994: 44-46). Human lives are not governed by dualities - even as these are its compositional units - but by trialities ${ }^{4}$. A triality is a temporalstructural unit which entails two mutually related opposites (duality) together with the structural conditions of its own transformation into a new form (which includes the maintenance of the old form). Figure 1 gives the generic structure of triality.

\footnotetext{
3 Which he himself tried to avoid.

4 It would be very interesting to see if the current habitual fights in the postmodern social sciences against "dualisms" become transformed into similar bashing of "trialisms".
} 


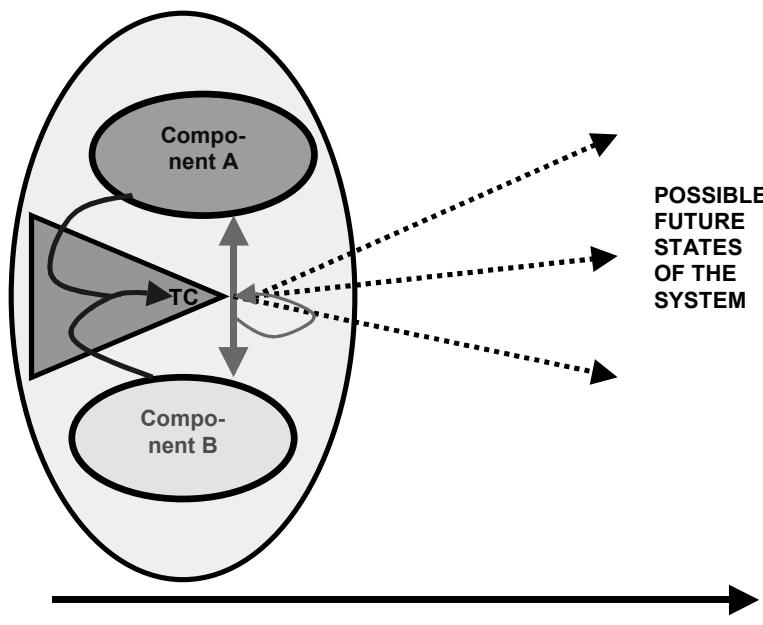

TIME

$\mathrm{TC}=$ Transformation Conditions

Figure 1. The generic structure of triality.

The centrality of "thirdness" in semiogenetic processes has been recognized in many areas of inquiry (Marcus 1997). It has been brought into psychology on its developmental and cultural sides (Marková 1990; Rosa 2007). The notion of triality opens the way for scientific discourses to consider the open-ended nature of developmental phenomena. Their structure is deterministically indeterministic (Valsiner 1997) - it has the current structure (with its history) that is expected to result in new versions - unpredictable in their specifics, yet predictable in their fact of being novel.

\section{Roots of triality: C. S. Peirce}

It is here where C. S. Peirce's semiotics meets the needs of developmental sciences. Peirce superimposed the mathematical demonstration of infinity from a geometric realm to that of time. If one were to explain infinity in case of dividing a line into sub-segments, this division (which itself is a discrete act of dividing a whole into two parts) process can be 
continued infinitely, with the result of dividing the line into infinitesimally small (and ever smaller) sub-parts. If, instead a geometric figure (line) there is the time, the time too can be divided into similar infinitesimally small segments (moments). Thus, the present in the infinitesimal time moment between the past and the future. As such, the experiencing organism cannot perceive it as "the present". All perception of the present, and reflection upon it in ideas, is already the next present's reconstruction of the immediate past.

The notion of the present is a boundary in the personal division of the past and future. For Peirce, "...the present is half past and half to come" (Peirce 1892/1923: 219). The moving boundary of the present is not that of a co-presence of the past and the future (as some kinds of existential "surfaces"), but a process of emergence. Peirce recognized this difference of the flow of consciousness-in-time (Peirce 1923 [1892]: 220).

How does the "birth of the next present" take place in the psychological domain? Peirce emphasized the role of generalization that operates between the fields of past re-constructions and future expectations. Development for Peirce entailed limitation of possibilities within a field (Peirce 1923 [1892]: 221). Peirce solves the problem of generalization through the notion of association:

A finite interval of time generally contains an innumerable series of feelings; and when these become welded together in association, the result is general idea. $[\ldots]$

The first character of a general idea so resulting is that of its living feeling. A continuum of this feeling, infinitesimal in duration, but still embracing innumerable parts, and also, through infinitesimal, entirely unlimited, is immediately present. (Peirce 1923 [1892]: 224, added emphases)

The person can overcome the limitations of the present through generalizing an idea reaching out into the past and future. Yet the general idea is immediately present in the form of a general feeling, in the boundary of the present. Signs operate in ways that prepare the sign-maker to face the next moment. 


\section{Autoregulatory and heteroregulatory sign processes}

The duality of human mind is paralleled by the triplicate nature of signs that regulate that mind. A use or invention of a word depicting something is not only referring to the denoted referent, but presenting that referent for some purposes, directions.

For instance, if I tell you that "this article is printed on white paper", I am not merely reiterating the obvious (which the reader can see anyway), but presenting that aspect of the environment for some purposes. I need not have specific goals while making such statement, yet the statement (about the obvious) is simultaneously re-presentation, co-presentation, and pre-presentation (Valsiner, 2001a; 2001b; 2002). The message is therefore necessarily ambiguous - in terms of representation it is true and obvious (the paper seems white indeed), while in terms of co-presentation it raises the question of "why is he pointing our attention to this particular ${ }^{5}$ fact?". Last (but not least) — the prepresentation entails communication about the future state of the object ("...but the paper will become yellow in 100 years" or "...but it is the waste of trees to make the paper on which this article is printed").

\section{Three levels of sign regulation}

How does a meaning-maker regulate one's mind? The semiotic/ historical view on signs considers those to be constantly oriented towards the immediate future of the present psychological processes. Signs function in parallel to accomplish three functions - maintain themselves (autoregulation), maintain their immediate next level signs (or lower psychological processes), or terminate further meaning-making (Fig. 2).

If we look at the Level $\mathrm{N}$ sign (in Figure 2), which can generate a higher level $(\mathrm{N}+1)$ meta-sign, or relate to other level-N signs, aside from regulating the subordinate process, then we see that each sign can be involved in three relations of autoregulatory kind at the same

\footnotetext{
5 Out of all possible features of the object to be emphasized. Specifically as we live in a pleromatic universe the possibilities for immediate co-presentation by the Sender and the Recipient are wide. So are their different interpretations of the message (Bühler 1934).
} 
time (downwards, upwards, and horizontally). While controlling and canalizing the flow of lived-through experience the signs are involved in "networking" (with other signs) and generalizing. Abstractive generalization is the basis for human empathy (Worringer 1911) and thinking (Bühler 1934). The person is ready for subjective synthesis in making sense of the world based on the mutuality of immediate life experience and pre-established meaning fields.

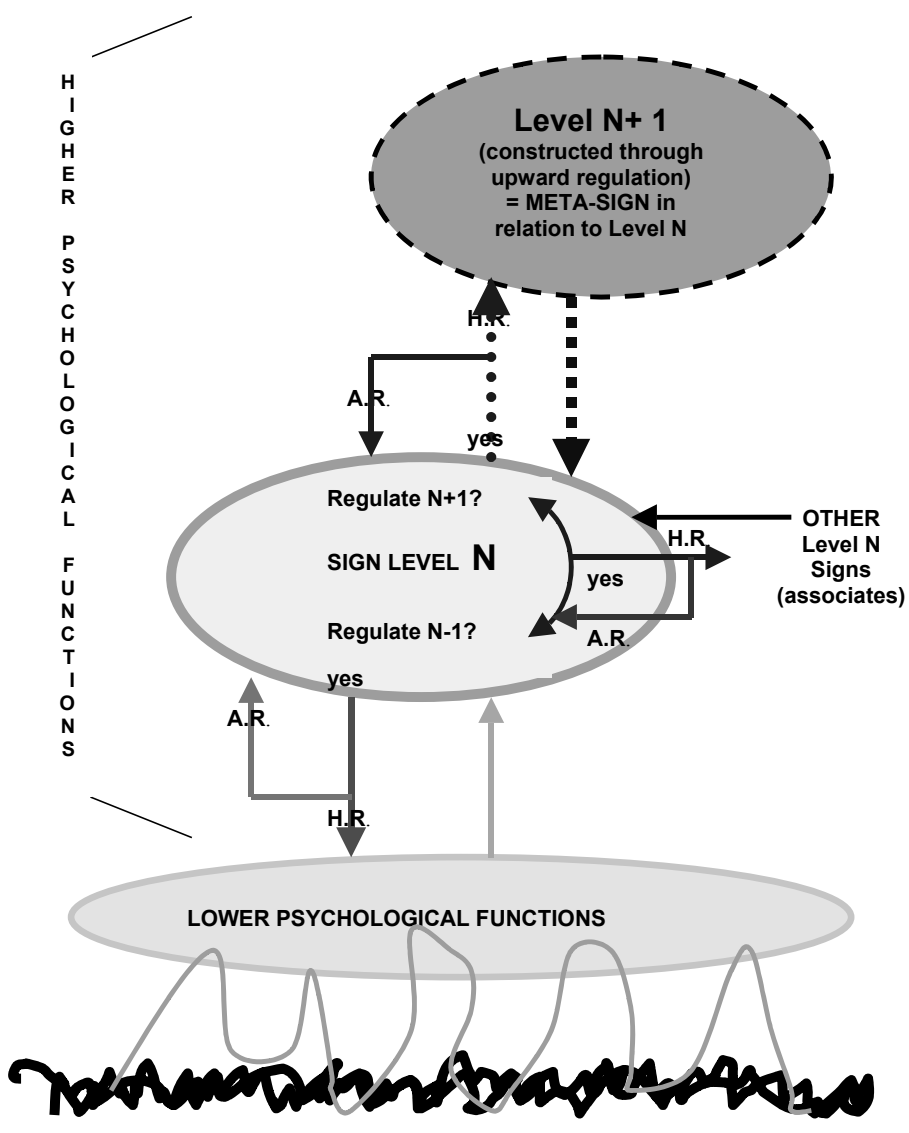

THE FLOW OF IMMEDIATE EXPERIENCE $\rightarrow$ time

Figure 2. Summary of the autoregulation (A.R.) and heteroregulation (H.R.) by signs in a dynamically changing semiotic hierarchy. 


\section{Jaan Valsiner}

The triality of the autoregulatory processes guarantee that any level of signs cannot be isomorphic with the lower processes (nor with one another). Here an interesting side issue is worth mentioning. Psychologists have disputed the issue of "consistency between behavior and self report", usually lamenting that such consistency is low. From the present viewpoint, low consistency is a necessary result from the role signs play in regulation of conduct. To expect full consistency here (i.e., that self-reports "fully and accurately" depict behavior) would deny both the heteroregulatory (H.R.) and autoregulatory (A.R.) functions of the signs.

From generalization to contextualizing specification

Two processes can be present in the regulatory hierarchies abstracting generalization and contextualizing specification. Abstracting generalization creates new levels of semiotic regulators, removing the re-co-pre-presentational role increasingly further towards higher complexity of abstraction. For example, human values are generalizations of abstracted kind. Extremely general terms like "love", "justice", "freedom" etc are meaningful in their overgeneralized abstractness.

As such, these generalized signs can be brought to bear upon regulating very specific contexts (by process we could call contextualizing specification). They operate in very concrete settings linking their abstracted properties with the specifics of a here-and-now setting. Through this process any momentous application of longestablished — and rarely used — generalized meaning in new contexts becomes possible. The immediate feeling of "this street looks dangerous" when a person is about to enter a dark alley is possible only through such specification. Prior to actual experience the meaning of "dangerous" as applied to "this X" (street, person, drug, activity, etc.) is re-presentationally a lie, co-presentationally a sign for checking consensus, and pre-presentationally a self-guiding device. We operate through such specification all the time - without it all our language use would remain purely re-presentational. 


\section{What is fun?}

Consider a very "trans-Atlantic" example — you may find many North Americans talking about something vague — yet (for them) very concrete - the notion of fun. That term is heard in social discourses in America all the time - and its collective-cultural power is precisely in its vagueness. Nobody can exactly define that term, but its use is possible across an immense variety of concrete contexts. So, Americans can "have fun" doing almost anything — from doing nothing to working hard on their self-created hobbies. When you are eating at a restaurant the waiter may come and ask "are you having fun with your steak?" and you may be uncertain what is implied. You hear people boasting how some event was "a lot of fun" — and again it is uncertain what it means. People can set up "fun" as the criterion for improvement (by making "having more fun" one's personal goalorientation) or even for competition ("I want to have more fun than John"). It is an open field for future psychologists to develop standardized methods for measurement of "having fun" (like there are so many standard methods for the study of anything in psychology).

The meaning of "fun" itself is in principle indeterminate, and in two ways. First, within a person's personal culture, it is an abstracted overgeneralization from a wide variety of personal life experiences of the past, linked with the language notion of "fun". The contrast here is with the opposite ("non-fun") that helps to specify boundary of the two for specific referents (e.g. "X is fun, Y is not fun"). Secondly and more importantly - for interpersonal communication, the notion of "fun" is completely indeterminate in its meaning, yet easily usable for creating a state of illusory intersubjectivity. Whatever is my personal-cultural background for making any statement, it is not revealed in the statement itself, which remains a widely open sign"blurb". Still, within the collective cultural world it does resonate on the side of recipients. The ill-defined notion fun is a result of subjective abstraction - and a tool for uses in any new contexts (specification). 


\section{Concluding point: Irreversibly constrained freedom for novel thinking}

The dynamic function of the triplet - new symbolic form, metasymbolic form, and regulation of the depth of hierarchy - creates a powerful mechanism of meaning making that adjusts well to many new contexts. Signs constrain actions, feelings about actions, and their own actions upon actions and mental processes. Yet they do not do it in a fixed way - instead of transitive hierarchies $(a>b, b>c, a>c)$ we may come across seemingly inconsistent intransitive hierarchies $(a>b$, $\mathrm{b}>\mathrm{c}$ and $\mathrm{c}>\mathrm{a}$ ) of signs - and of the relations between sign makers and signs. Thus - indeed we construct thought, become guided by the thought - and yet our subservience to the thought that guides us is made up by ourselves (Valsiner 1999). The maker becomes the made and moves on to be the maker for the something new. Our life experiences are grown into our personal cultures. That makes human way of meaningful living possible. Personal cultures operate through semiotic abstractive generalizations that feed forward into reorganization of the social world - which then gives further rise to personal-cultural meaningfulness. Semiosis at the personal level is infinite in its constant production of novelty until the person lives. Human beings are consistent in their capacity for becoming inconsistent with their pasts. This provides them with a basis for adaptation that goes beyond the given environment. Such permanent transcendence is the essence of all living. Its human form is characterized by a new form of triality - that of creating a sign as if it had always been there in its givenness.

\section{References}

Baldwin, James Mark 1906. Thought and Things: A Study of the Development and Meaning of Thought, or Genetic Logic, vol. 1. Functional Logic, or Genetic Theory of Knowledge. London: Swan Sonnenschein \& Co.

\footnotetext{
A previous version of this paper was prepared initially as a seminar presentation at the Seminar on Symbolic Forms at École Normale Supérieure, Paris, February 6, 2004, and is available at http://formes-symboliques.org/article.php3?id_article $=46$
} 
Bergson, Henri 1945 [1907]. L'Évolution créatrice. Genève: Éditions Albert Skira.

- 1911a. Creative Evolution. New York: Henry Holt \& Co.

- 1911b. Matter and Memory. London: George Allen \& Unwin. [English translation of Bergson 1896, Matière et mémoire. Paris: Felix Alcan.]

Bühler, Karl 1934. Sprachtheorie. Jena-Stuttgart: Gustav Fischer. [English translation 1990.]

Eichinger Ferro-Luzzi, Gabriella 2002. The mental monkey: the mind in modern Tamil literature. Zeitschrift der Deutschen Morgenländischen Gesellschaft 152(1): 113-131.

Marcus, Solomon 1997. Three. In: Rauch, I.; Carr, G. F. (eds.), Semiotics Around the World: Synthesis in Diversity. Berlin: Mouton de Gruyter, 773-776.

Marková, Ivana 1990. A three-step process as a unit of analysis in dialogue. In: Marková, Ivana; Foppa, Klaus (eds.), The Dynamics of Dialogue. Hemel Hempstead: Harvester, 129-146.

Nöth, Winfried 1994. Opposition at the roots of semiosis. In: Nöth, Winfried (ed.), Origins of Semiosis: Sign Evolution in Nature and Culture. Berlin: Mouton de Gruyter, 37-60.

Oliveira, Zilma de Novaes Ramos de; Valsiner, Jaan 1997. Play and imagination: the psychological construction of novelty. In: Fogel, A.; Lyra, M. C. D. P.; Valsiner, J. (eds.), Dynamics and Indeterminism in Developmental and Social Processes. Mahwah: Lawrence Erlbaum Associates, 119-133.

Peirce, Charles Sanders 1923 [1892]. The law of mind. In: Peirce, C. S., Chance, Love and Logic. London: Kegan Paul, Trench, Trubner \& Co., 202-237.

Prigogine, Ilya 1973. Irreversibility as a symmetry-breaking process. Nature 246: 67-71.

Ravenhill, Phillip L. 1996. Dreams and Reverie Images of Otherworld Mates Among the Baoule, West Africa. Washington: Smithsonian Institution Press.

Rosa, Alberto 2007. Acts of Psyche: Actuations as synthesis of semiosis and action. In: Valsiner, Jaan; Rosa, Alberto (eds.), Cambridge Handbook of Socio-Cultural Psychology. New York: Cambridge University Press, 205237.

Salgado, João; Gonçalves, Miguel 2007. The dialogical self: social, personal, and (un)conscious. In: Valsiner, Jaan; Rosa, Alberto. (eds.), Cambridge Handbook of Socio-Cultural Psychology. New York: Cambridge University Press, 608-621.

Valsiner, Jaan 1997. Culture and the Development of Children's Action. 2nd ed. New York: Wiley.

- 1999. I create you to control me: A glimpse into basic processes of semiotic mediation. Human Development 42: 26-30. 


\section{Jaan Valsiner}

- 2000. Thinking through consequences: the perils of pragmatism. Revista de Historia de la Psicologia 21(4): 145-175.

- 2001a. Comparative Study of Human Cultural Development. Madrid: Fundacion Infancia y Aprendizaje.

- 2001b. Process structure of semiotic mediation in human development. Human Development 44: 84-97.

- 2002. Irreversibility of time and ontopotentiality of signs. Estudios de Psicologia 23(1): 49-59.

- 2005. Affektive Entwicklung im kulturellen Kontext. In: Asendorpf, J. B. (ed.), Enzyklopädie der Psychologie, vol. 3. Soziale, emotionale und Persönlichkeitsentwicklung. Göttingen: Hogrefe, 677-728.

- 2006. The semiotic construction of solitude: Processes of internalization and externalization. Sign System Studies 34(1): 9-35.

- 2007. Culture in Minds and Societies. New Delhi: Sage.

Valsiner, Jaan; Veer, René van der 2000. The Social Mind. New York: Cambridge University Press.

Valsiner, Jaan; Diriwächter, Rainer; Sauck, Christine 2005. Diversity in unity: standard questions and nonstandard interpretations. In: Bibace, R.; Laird, J. D.; Noller, K. L.; Valsiner, J. (eds.), Science and Medicine in Dialogue: Thinking Through Particulars and Universals. Westport: Praeger, 289-307.

Veer, René van der; Valsiner, Jaan 1991. Understanding Vygotsky: A quest for synthesis. Oxford: Basil Blackwell.

Vogel, Susan M. 1997. Baoule: African Art, Western Eyes. New Haven: Yale University Press.

Wagoner, Brady; Valsiner, Jaan 2005. Rating tasks in psychology: from static ontology to dialogical synthesis of meaning. In: Gülerce, A.; Hofmeister, A.; Staeuble, I.; Saunders, G.; Kaye, J. (eds.), Contemporary Theorizing in Psychology: Global Perspectives. Toronto: Captus Press, 197-213.

Worringer, Wilhelm 1911. Abstraktion und Einfühlung. München: R. Piper \& Co.

Zittoun, Tania 2006. Transitions. Greenwich: Information Age Publishers.

- 2007. The role of symbolic resources in human lives. In: Valsiner, Jaan; Rosa, Alberto (eds.), Cambridge Handbook of Socio-Cultural Psychology. New York: Cambridge University Press, 343-361.

Zittoun, Tania; Duveen, Gerard; Gillespie, Alex; Ivinson, Gabrielle; Psaltis, Charis 2003. The use of symbolic resources in developmental transitions. Culture \& Psychology 9(4): 415-448. 


\section{Семиотическая саморегуляция: как динамические иерархии знаков организуют течение сознания}

Во всех гуманитарных науках для понимания функционирования сознания необходимо наличие новой теории, которая исходила бы из предпосылки, что количество символических форм в человеческой культуре в принципе бесконечно. Эти формы сознания порождаются бесконечным числом уникальных встреч человека с окружающим миром. Теория символических форм должна учитывать, что течение сознания и действие по существу являются гипердинамичными и необратимыми. Человеческое сознание регулируется динамической иерархией семиотических систем, причем каждый новый уровень в этой иерархии более универсален и отдельные уровни взаимодействуют между собой. Доказано, что семиотическое опосредование создает в конструкциях между отдельной личностью и культурой триаду: новая символическая форма, метасимволическая форма и регулятивный сигнал, который останавливает или инициирует возникновение следующего уровня семиотической иерархии. Выражаясь более простым языком, человеческие существа создают новые проблемы, а заодно и новые попытки разрешения этих проблем, и принимают решение, когда остановить генерирование проблем и их разрешений. Таким образом семиотическое опосредование путем абстрагирующего обобщения и контекстуализирующего определения одновременно укрепляет как гибкость, так и ригидность психологической системы человека. Зависимость психологических процессов от контекста является знаком наличия общих механизмов, создающих разнообразие. Исследование сложной психики человека обязательно должно сосредоточиваться на анализе многообразия психологического хронотопа отдельных личностей.

\section{Semiootiline eneseregulatsioon: kuidas dünaamilised märgihierarhiad piiravad teadvusekulgu}

Kõigis humanitaarteadustes on teadvuse toimimise mõistmiseks vajalik uue teooria olemasolu, mis lähtuks eeldusest, et sümboliliste vormide hulk inimkultuuris on põhimõtteliselt lõputu. Sümbolilised vormid on sotsiaalselt konstrueeritud inimese poolt, liikudes läbi maailmaga ainukordsete kohtumiste lõputu hulga. Sümboliliste vormide teooria peab võtma arvesse teadvusevoolu ja tegevuse olemuse, mis on oma loomult 
hüperdünaamilised ning pöördumatud. Inimese vaimu reguleerib semiootiliste mehhanismide dünaamiline hierarhia, mille iga uus tasand on järjest üldisem ning mille tasandid limiteerivad üksteist. On tõestatud, et semiootiline vahendamine tekitab üksikisiku ja kultuuri vaheliste konstruktsioonide kolmiku: uus sümboliline vorm, metasümboliline vorm ja regulatiivne signaal, mis peatab või algatab semiootilise hierarhia järgneva tasandi tekkimise. Ehk tavakeelsemalt: inimolendid tekitavad probleeme lahendades uusi probleeme ja uusi püüdlusi ning võtavad vastu otsuseid, millal probleemide ja lahenduste genereerimine järele jätta. Seega kindlustab semiootiline vahendamine abstraheeriva üldistuse ja kontekstualiseeriva määratlemise protsesside kaudu ühtaegu nii inimese psühholoogilise süsteemi paindlikkuse kui ka selle jäikuse. Psühholoogiliste protsesside kontekstispetsiifilisus on märk mitmekesisust loovate üldiste mehhanismide olemasolust. Inimeste keerulise psüühika uurimine peab tingimata keskenduma üksikisikute psühholoogilise aegruumi mitmekesisuse analüüsile. 